\title{
DIGITAL TRANSFORMATION OF THE BELARUS ECONOMY (ADAPTA- TION OF WORLD EXPERIENCE)
}

\author{
Alexander Baranov ${ }^{1}$ \\ ${ }^{1}$ Assoc. Prof., PhD in Economics, Department of economic theory and world economy, F. Scorina Gomel State Universi- \\ ty, 246019, Belarus, Gomel 104 Sovetskaya str., Phone No.+375295372921, E-mail address: axmbaranov@inbox.ru
}

Received 2610 2021; Accepted 04112021

\begin{abstract}
The author systematizes approaches to the concept of digital economy and presents an analysis of the key indicators of digitalization development in the countries worldwide. The pace of economy digitalization in the world community is compared based on the increase of expenditures for ICT accompanied by mass digitalization. The author investigates main priorities of the development of digital economy of Belarus, analyzes technological indicators of the development of the digital economy of Belarus in comparison with the indicators of developed countries and countries with economies in transition. The research consideres industrial and informational scenarios for the development of the Belarusian economy. Object of research: digital economy as a basis of economic development of Belarus. Purpose of research: analysis of the digital transformation of the Belarus economy in comparison with developed countries and countries with economies in transition. Methodology of investigation: the analysis and synthesis of scientific literature, method of the composite indicator complementary method of information-anthropogenic analysis.
\end{abstract}

Keywords: information, digital economy, knowledge, intellectual potential.

JEL Codes: F63, O31, O33.

\section{Introduction}

The process of formation of the digital economy is a complex phenomenon associated with changes in the system of productive forces and social relations. Due to the search for promising options for the further development of the state, research in the field of the digital economy is becoming relevant. Such studies are of particular importance for Belarus, where infrastructural changes in the direction of informatization have recently begun to be observed, the number of Internet users is increasing, the country's position in the application of information technologies (IT) is strengthening, and the number of innovatively active enterprises is growing. Moreover, the Republic of Belarus has significant intellectual potential. All this will contribute to ensuring stable economic growth and taking a worthy place in the world economy.

\section{Objectives and methods}

According to several economists (Radu \& Podașcă, 2013; Burma, 2016; Glushkova et al., 2019), digital technology is a product of the Fourth Industrial Revolution, which has set the economy to radical changes. Digital innovations contribute to the development of a new economic order, sometimes called digital economy, information economy, virtual economy, or network economy.

These new structures open previously unknown opportunities for society, business, and the state. The literature provides a diverse understanding of the essence of digital economy. Fayyaz (2019) characterizes information economy as a system of economic, social and cultural relations that are based on digital technologies. This is a broad approach that embraces the whole spectrum of social relations. At that, the said definition refers to a more general meaning.

Copyright (C) 2021 Author(s), published by Vytautas Magnus University. This is an open access article distributed under the terms of the Creative Commons Attribution Non-Commercial 4.0 (CC BY-NC 4.0) license, which permits unrestricted use, distribution, and reproduction in any medium provided the original author and source are credited. The material cannot be used for commercial purposes. 
In our opinion, information economy stands out with how goods and services are developed, produced, and sold (i.e. via digital technologies). Aguila, Padilla, Serarols \& Veciana (2003) hold a similar view. Huckle, Bhattacharyaa, Whitea \& Beloffa (2016), D'Souza \& Williams (2017), and Barefoot,Curtis, Jolliff, Nicholson Omohundro (2018) detail the diversity of digital technologies. Autio, Nambisan, Thomas \& Wright (2018) focus on the fundamental changes in business organization, which take place during the period of digital transformation.

The above works throw light on the certain aspects concerning the functioning of digital economy that together portray its essence. A narrow view of these works necessitates systematization of approaches towards the research on digital economy.

Our proposed complementary method of information-anthropogenic analysis in the study of complex systems (Baranov, 2017), which include a set of institutions digital economy, allows to establish a single manifestation of the substantial nature of the components of the information system model. A single common basis of information at the substantial level, that is, information interaction, makes the various elements of the model digital economies are qualitatively homogeneous and comparable to each other. All external forms of expression and characteristics inherent in various forms of intellectual potential can be reduced to its informational components. Digital economy dominated by highly intellectual socio-economic structures, a technological base of social intelligence is being formed, which is characterized by: a) a network structure; b) highly developed means of communication; c) social memory; d) the existence of a layer of the highly intellectual elite; e) highly qualified specialists; f) the presence of an intelligent market for the exchange of ideas and information.

\section{Results and its discussion}

It is no coincidence that many experts (Radu \& Podașcă, 2013; Burma, 2016; Glushkova et al., 2019, Titova, 2009), considering the transition of the state to the information society, place the subject of the labor market at the center of the information environment. We fully agree with this approach and, on the basis of the complementary method of information-anthropogenic analysis, we consider that the intangible good, being included in economic flows, makes it possible to increase the level of organization of the economic space and society (Figure 1).

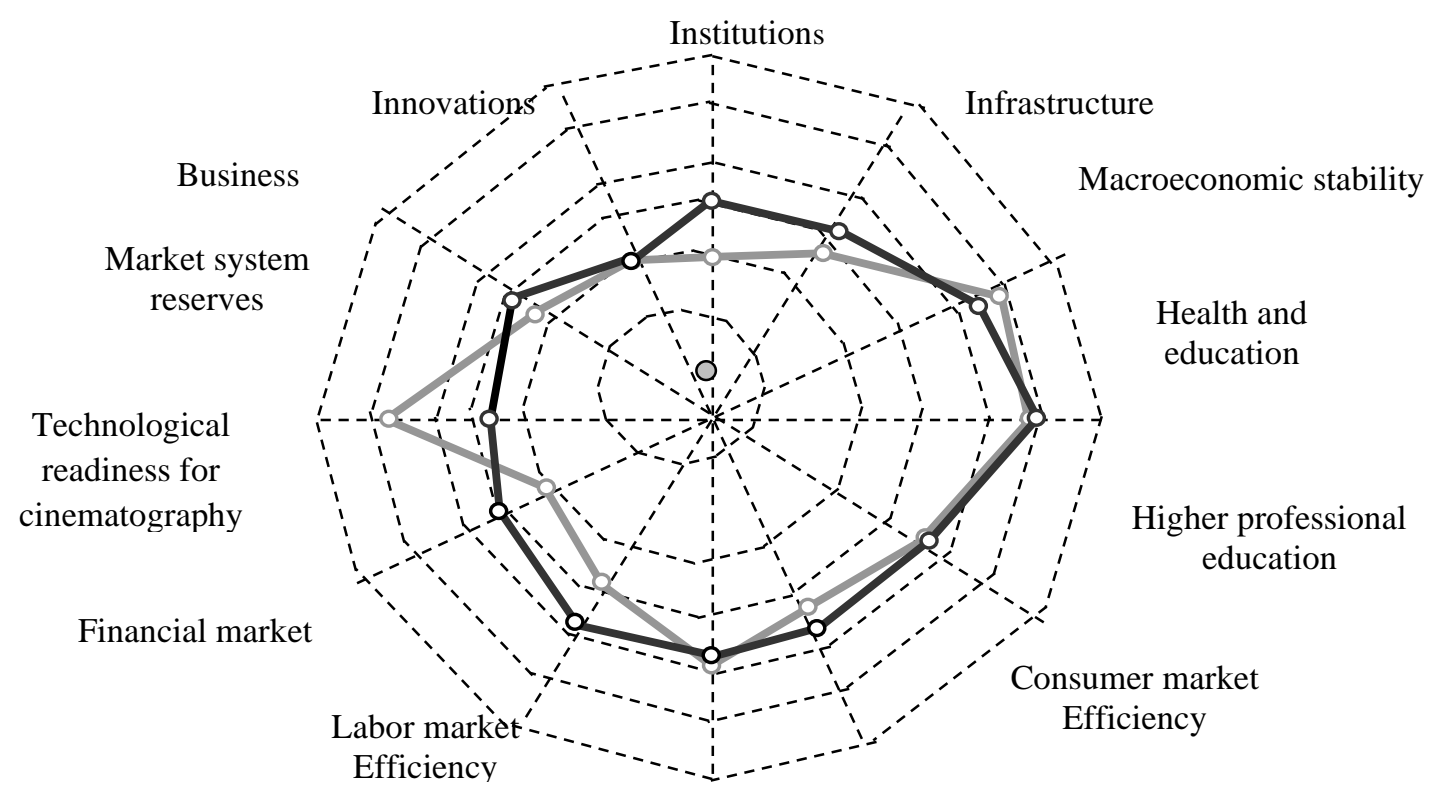

Economy of Belarus in the transition to the information stage of development

Economic systems

Figure 1. Scheme of development of the information economy of Belarus 


\title{
Sciendo
}

\author{
Management Theory and Studies for Rural Business and Infrastructure Development \\ eISSN 2345-0355. 2021. Vol. 43. No. 4: 536-544 \\ Article DOI: https://doi.org/10.15544/mts.2021.48
}

As reflected in Figure 1, technological readiness for innovation is one of the main factors in building an effective digital economy in Belarus. A well-developed information infrastructure makes it possible to increase the frequency of innovations, which, in ag- gregate, turn into an innovation stream. In this sense, the digital economy is presented as an economy of innovation flows, leading, ultimately, to the formation of new socioeconomic relations.

Table 1. Indicators of the development of the information sector of the economy

\begin{tabular}{|c|c|c|c|}
\hline Sector & Designation & Name & $\begin{array}{l}\text { Units } \\
\text { measurements }\end{array}$ \\
\hline \multirow{2}{*}{ 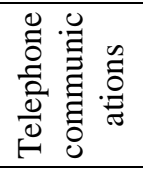 } & $x 1$ & Telephone density of public networks & $\begin{array}{l}\text { Number of subscribers to main } \\
\text { networks per } 1000 \text { people }\end{array}$ \\
\hline & $x 2$ & $\begin{array}{l}\text { Density of mobile telephony per } 1000 \text { popula- } \\
\text { tion }\end{array}$ & $\begin{array}{l}\text { Number of mobile network } \\
\text { subscribers per } 1000 \text { people }\end{array}$ \\
\hline \multirow{2}{*}{ 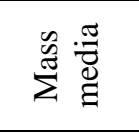 } & $x 3$ & Television coverage of households & $\%$ \\
\hline & $x 4$ & $\begin{array}{l}\text { Number of copies of one-time circulation of } \\
\text { daily newspapers per } 1000 \text { population }\end{array}$ & $\begin{array}{l}\text { Number of copies per } 1000 \\
\text { people }\end{array}$ \\
\hline \multirow{7}{*}{ 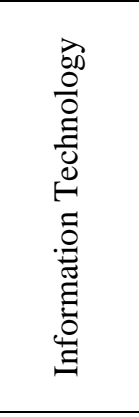 } & $x 5$ & Personal computers per 1000 population & PCS. for 1000 people \\
\hline & $x 6$ & $\begin{array}{l}\text { The number of secure Internet servers (hosts) } \\
\text { per } 1,000,000 \text { population }\end{array}$ & PCS. per million people \\
\hline & $x 7$ & Share of Internet users in the total population & $\begin{array}{l}\begin{array}{l}\text { Number of users per } 1000 \\
\text { people }\end{array} \\
\end{array}$ \\
\hline & $x 8$ & Broadband subscribers per 1000 people & $\begin{array}{l}\begin{array}{l}\text { Number of users per } 1000 \\
\text { people }\end{array} \\
\end{array}$ \\
\hline & $x 9$ & International internet bandwidth & Bit per capita \\
\hline & $x 10$ & Online shopping cart price & Doll. per month \\
\hline & $x 11$ & ICT spending & Doll. per capita \\
\hline \multirow{3}{*}{.0ี } & $x 12$ & $\begin{array}{l}\text { Share of secondary school students in the total } \\
\text { population of this age category }\end{array}$ & $\%$ \\
\hline & $x 13$ & $\begin{array}{l}\text { The share of students in higher education in the } \\
\text { total population of this age category }\end{array}$ & $\%$ \\
\hline & $x 14$ & Public spending on education & Doll. per capita \\
\hline \multirow{6}{*}{ 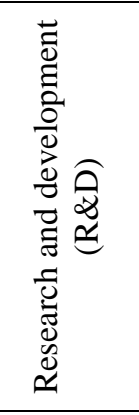 } & $x 15$ & Provision of scientific research by scientists & $\begin{array}{l}\text { Number of researchers per } \\
\text { million people }\end{array}$ \\
\hline & $x 16$ & Number of engineers in scientific research & $\begin{array}{l}\text { Number of engineers per mil- } \\
\text { lion people }\end{array}$ \\
\hline & $x 17$ & Research and development costs & Doll. per capita \\
\hline & $x 18$ & High technology export value & Doll. per capita \\
\hline & $x 19$ & $\begin{array}{l}\text { Intellectual Independence Ratio }=\text { royalties } \\
\text { and royalties received by a country versus } \\
\text { royalties and royalties transferred }\end{array}$ & $\%$ \\
\hline & $x 20$ & Patent applications registered & PCS. per million people \\
\hline
\end{tabular}

According to the technique developed by N.V. Baranova (Baranova, 2007), the assessment of the level of development of the information sector of the Belarusian economy in comparison with developed countries and countries with economies in transition was carried out in the context of:
1) the telecommunications sector (in terms of the provision of telephone services, media, IT) to gain access to information (network) resources;

2) the scientific and educational sphere (in terms of the provision of the population with educational services, as well as the re- 
sults of research activities), which is reflected in Table 1.

The following requirements were imposed on the selected indicators:

- for the objectivity of the assessment, each industry should be characterized by several indicators;

- indicators should be secondary (calculated) to ensure their comparability at the level of countries with different population sizes.

All of the above sectors in each country provide the necessary information reproduction processes associated with the generation and processing of knowledge and information, their distribution (dissemination), exchange and consumption. In each country, the implementation of the stages of social reproduction of information and knowledge has different possibilities, since it is explained by the degree of development of these sectors in a given period.

The clustering of countries according to the criteria given in Table 1 was carried out by the K-means method using the STATISTICA 6.0 programm. As a result of the analysis, clusters were obtained that confirm the existence of differences in the emerging digital economy of developed and countries with economies in transition. For each country, according to the method of the composite indicator, generalized characteristics of the level of development of the IT sector and the sphere of research and development were calculated, since it was in these sectors that the heterogeneity of development manifested itself, which led to the typology of the digital economy (Table 2).
The algorithm for determining the aggregate indicator (SP) in relation to this study is as follows:

- the set $\{\mathrm{xl}\}(l=\overline{1, k})$ indicators characterizing the influence of the selected sectors on the processes of informatization of society in different countries;

- a set is formed, characterized by the initial indicators;

- all indicators are standardized based on the calculation of the values of the uniform distribution function;

- for each cluster, summary indicators of the level of development of individual sectors are determined. Summary indicators are calculated using the arithmetic mean formula for each country and characterize the generalized impact of the selected sectors on the level of economic development.

The limits of change in the values of the summary indicators for IT and research, according to the calculation method, range from 0 to 1 , respectively, the better the state of the phenomenon, the closer the indicator is to 1 .

The index of GDP per capita was chosen as an indicator characterizing the state of the country's economic development. According to the table 1 in the formed clusters, the level of GDP per capita of the countries is comparable in value, this is especially noticeable in the group of countries with economies in transition. The obtained result of generalization of indicators made it possible to position countries from the considered groups according to the level of development of two key sectors of the digital economy - the IT sector and the R\&D sector (Baranov, 2020). 


\section{Sciendo}

Management Theory and Studies for Rural Business and Infrastructure Development

eISSN 2345-0355. 2021. Vol. 43. No. 4: 536-544

Article DOI: https://doi.org/10.15544/mts.2021.48

Table 2. Generalized characteristics of the level of informatization

\begin{tabular}{|c|c|c|c|c|c|}
\hline $\begin{array}{l}\text { Clusters } \\
\text { (IT-R\&D) }\end{array}$ & No. & Country & IT JV & $\begin{array}{l}\text { SP on } \\
\text { research }\end{array}$ & GDP per capita \\
\hline \multicolumn{6}{|c|}{ Countries with economies in transition } \\
\hline \multirow[b]{4}{*}{$1-2$} & 1 & Poland & 0.117 & 0.051 & 0.159 \\
\hline & 2 & Slovakia & 0.178 & 0.112 & 0.191 \\
\hline & 3 & Lithuania & $\approx 0.164$ & 0.073 & 0.174 \\
\hline & 4 & Latvia & $\approx 0.223$ & 0.084 & 0.148 \\
\hline \multirow[b]{2}{*}{$1-3$} & 5 & Czech & 0.197 & 0.145 & 0.263 \\
\hline & 6 & Hungary & 0.128 & 0.167 & 0.250 \\
\hline $2-2$ & 7 & Estonia & $\approx 0.420$ & 0.114 & 0.217 \\
\hline $3-1$ & 8 & Russia & 0.039 & 0.123 & 0.101 \\
\hline \multirow[b]{2}{*}{$3-2$} & 9 & Bulgaria & 0.068 & 0.063 & 0.078 \\
\hline & 10 & Belarus & 0.022 & 0.067 & 0.058 \\
\hline \multirow[b]{2}{*}{$3-4$} & 11 & Kyrgyzstan & $\approx 0.014$ & 0.091 & 0.011 \\
\hline & 12 & Moldavia & $\approx 0.035$ & 0.054 & 0.015 \\
\hline $3-5$ & 13 & Romania & 0.077 & 0.035 & 0.085 \\
\hline \multicolumn{6}{|c|}{ Developed countries } \\
\hline $1-1$ & 1 & United Kingdom & 0.579 & $\approx 0.352$ & 0.889 \\
\hline \multirow[b]{2}{*}{$1-2$} & 2 & Sweden & 0.677 & $\approx 0.651$ & 0.965 \\
\hline & 3 & Netherlands & 0.623 & 0.457 & 0.891 \\
\hline $2-1$ & 4 & Canada & 0.568 & $\approx 0.260$ & 0.766 \\
\hline $2-3$ & 5 & USA & 0.647 & $\approx 0.577$ & 1 \\
\hline \multirow[b]{2}{*}{$3-1$} & 6 & Germany & 0.416 & 0.382 & 0.833 \\
\hline & 7 & France & 0.349 & $\approx 0.382$ & 0.850 \\
\hline \multirow[b]{2}{*}{$3-2$} & 8 & Finland & 0.500 & 0.643 & 0.897 \\
\hline & 9 & Japan & 0.481 & 0.549 & 0.907 \\
\hline
\end{tabular}

*Source: own research

The main determinant of the development of the digital economy of the Republic of Belarus is the development of human capital and the creation of conditions for its transformation into intellectual capital.

Intellectual capital has a direct impact on the dynamics and structure of production in both the material and non-material sectors of the economy. With an increase in the volume of production, the costs of the information factor of production - intellectual capital - increase. When the volume of this factor is limited, its cost increases, which leads to an increase in the cost of production. The degree of restriction is determined by the ratio of the amount of intellectual capital and the amount of current production. To describe this process, we use the O.S. Sukharev model (O.S.
Sukharev, 2008) which includes three main variables:

- the production volume;

- the amount of available material resources R;

- the amount of intellectual capital A.

Let the volume of material resources $\Delta \mathrm{R}$ be used in the production process, obtained as a result of the costs of the product created in the past year in the field of material resources. As a result, a new production volume is created:

$$
X(t+1)=p \Delta R(t)
$$

With an increase in the amount of intellectual resources, the value of $p$ will increase, therefore, the model uses the dependence: 


$$
P=P_{0}+A p_{1}
$$

Expenditures on intellectual capital are $\mathrm{M}=\mathrm{eX}$, while the specificity of the intellectual sphere is such that the rate of its growth is fundamentally limited. Finally, the amount of intellectual resources next year is equal to:

$$
A(t+1)=q A(t)+f \frac{M}{1+M / A}
$$

where the q coefficient shows the degree of disintegration of intellectual capital (mastering knowledge takes time, knowledge can become outdated);

coefficient $\mathrm{f}$ is the growth rate with effective (full-fledged relative to the need) financing;

$$
1 /(1+M / A)-\text { the }
$$

effectiveness of financing.

The volume of material resources $R$ usually has the same scale as X. Every year, a part of $\Delta \mathrm{R}$ spent on production is deducted from it, and part of the resources is renewed naturally. The model uses the ratio $\Delta \mathrm{R}=\mathrm{X} /$ $(1+g(X / R))$, where $g$ is a coefficient reflecting the price of resources. In addition, it is proposed to use a function of the form $\mathrm{b}$ (A / Ac) $\mathrm{k}$ to take into account the possibility of assimilating new information resources by society at the expense of information production factors. Here $b$ is the parameter of application of information innovations; $A$ is a certain critical level of development of the intellectual sphere. The value $k$ is a parameter that determines the effectiveness of scientific and educational activities, $t k$ - the time required to integrate an employee into the production process.

The growth rate of intellectual resources is equal to:

$$
V_{1}=\frac{d I}{d t}=\frac{d A 1}{d t}=k_{1} I
$$

where $\mathrm{I}=\mathrm{eX}-$ the volume of investments in the intellectual sphere;

$A 1$ - increase in the amount of intellectual resources through investments.

The decay rate of intellectual resources is equal to:

$$
V_{2}=\frac{d A_{2}}{d t}=k_{2} A
$$

then

$$
V_{A}=\frac{d A}{d t}=\frac{d A_{1}+d A_{2}}{d t}=k_{1} I-k_{2} A
$$

Having made the necessary transformations, you can write:

$$
\frac{d A}{d t}=k_{1} I_{0} e^{-k 1 t}-k_{2} A
$$

Carrying out the necessary transformations and multiplying all the terms by integration in the range from $\mathrm{t}=0$ to $\mathrm{t}$ and from $\mathrm{A}$ $=0$ to $\mathrm{A}$, we get:

$$
A=\frac{k_{1} I_{0}}{k_{2}-k_{1}}\left(e^{-k 1 t}-e^{-k 2 t}\right)
$$

Finally, we get the system of equations:

$$
\begin{aligned}
& X(t+1)=\left(p_{0}+p_{1} A(t)\right) \frac{X R}{R+g X}, \\
& R(t+1)=R(t)-\frac{X R}{R+g R}+h+[A(t)+\alpha A(t)(A \max -A(t))], \\
& A(t)=\frac{k_{1} e X}{k_{2}-k_{1}}\left(e^{-k 2 t}-e^{-k 1 t}\right),
\end{aligned}
$$

where $X(t)$ is the volume of production (performance efficiency);

$R(t)$ - the amount of available resources;

$A(t)$ - the level of intellectual potential;

$k_{1}, \mathrm{k}_{2}-$ constants of the intensity of parameters change;

$\alpha$-coefficient of growth of intellectual potential;

$g, p$ - coefficients of transitivity;

$h$ - parameter of information innovation application.

Applying this model, one can consider various scenarios for the development of the digital economy of the Republic of Belarus.

1. At the initial stage of economic development, Belarus does not have a technologically advanced production, but it has a large amount of unused human and intellectual capital. Let's consider an industrial (noninformational) scenario for the development 


\section{Sciendo}

Management Theory and Studies for Rural Business and Infrastructure Development eISSN 2345-0355. 2021. Vol. 43. No. 4: 536-544

of the Belarusian economy (Figure 2). Let's say that at the expense of foreign investments, we will ensure a rapid and significant (several times) increase in the scale of production. With appropriate financing of the intellectual sphere, its volume also increases several times. If intellectual capital is not used in production (and the parameter of application of information innovations is $b=0$ ), then economic growth will be short-lived. There will be a fairly rapid depletion of material factors of production, and when their volume falls below a certain level, a rapid decline in economic development will begin.

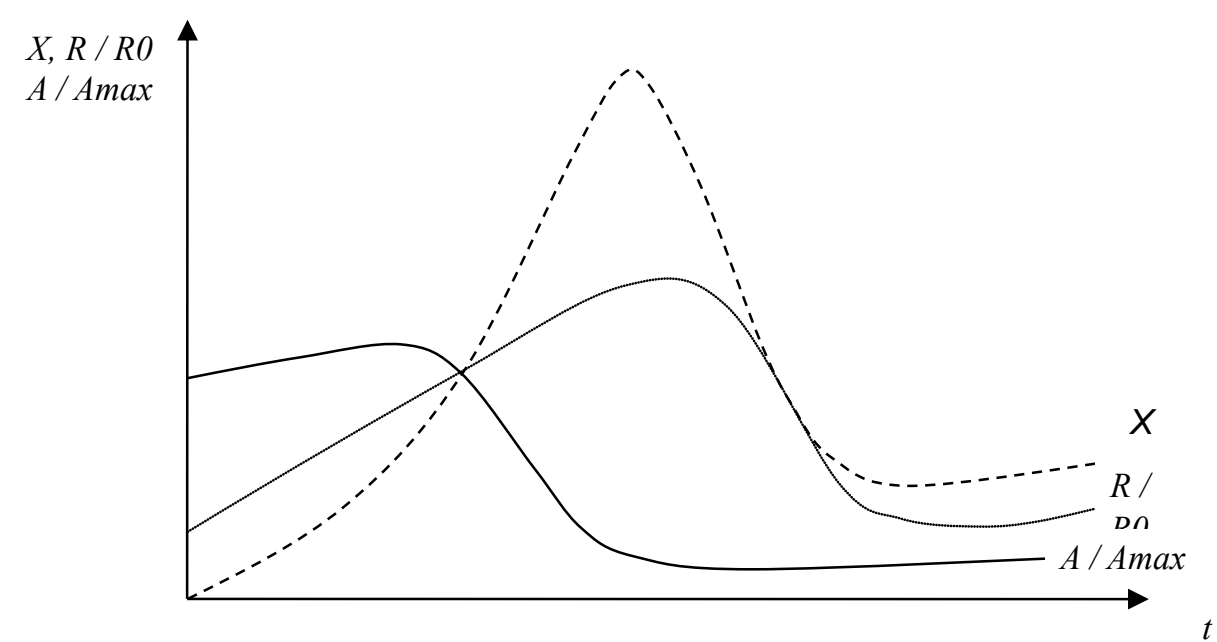

Figure 2. Development of the Belarusian economy with ineffective use of intellectual capital

2. Under the informational scenario of the development of the Belarusian economy, let us assume that the initial parameters have not changed in the economy, but institutional changes have taken place associated with the use of information innovations. In the model, this is equivalent to increasing the parameter $b$ to 1.5 . At the same time, the volume of pro- duction falls to $30 \%$, then there is a rapid recovery and a steady growth is observed. Thus, the economy reaches such a level of technological development that the sectors of the economy, the main factors of production are replaced by informational ones, and further growth is provided exclusively by the information and intellectual sphere (Figure 3). 


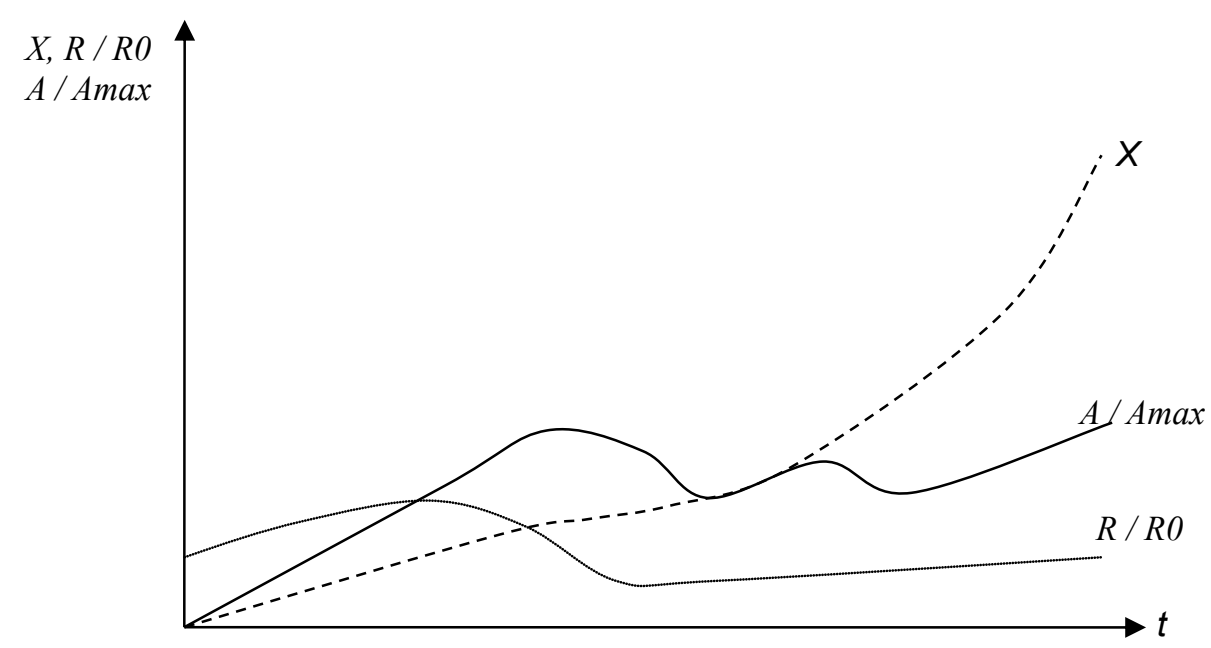

Figure 3. Development of the Belarusian economy with the effective use of intellectual capital

This situation means the strategy of "innovative breakthrough", when the country can become one of the highly developed countries. This requires overcoming the dysfunctional states of all economic subsystems, which means a high level of application of information innovations, the use of intellectual capital as a factor of production.

\section{Conclusions}

According to the results of positioning, Belarus is at the very beginning of the trajectory of world information development. The reasons for the current situation should be named: the lag in information literacy of the population, underestimation of intellectual resources, slow adaptation of the education system to the needs of the information society. To improve its position, Belarus needs to move from the policy of "adaptive digital economy" to the policy of "progressive digital economy", moving in the direction of the trajectory of world information development. This requires an intensive information and scientific and technical policy.

In Belarus, the branches of the electronic industry, in which hardware devices are produced, have not received proper development. Lacking our own hardware industry, we lagged behind the US and EU countries for several decades, in this regard, our information sector of the economy should develop towards the production of information products and services that require highly skilled labor. The potential of intellectual resources in our country is significant due to the existing education system.

\section{References}

Aguila, A., Padilla, A., Serarols, C., \& Jose, M (2003). Veciana Digital economy and management in Spain // Internet Research. Vol. 13(1): 6-16.

Autio, E., Nambisan, S., Thomas, L.D.W., Wright, M. (2018). Digital affordances, spatialaffor dances, and the genesis of entrepreneurial ecosystems // Strategic Entrepreneurship Journal Vol. 12(1): 72-95. Vol 1: 70-74

Baranov A.M. (2017) Information economy of Belarus and allocation of social capital // Ekonomické trendy.

Baranov A.M. (2017) Information economy and work in the sphere of knowledge // 21 century: fundamental science and technology XI: proceedings of the conference, SC, USA: CreateSpace. North Charleston. Vol 2: 233-236

Baranov A.M. (2020) Education 2.0 in Europe and cyberreadiness: France experience // Magyar Tudományos Journal. Vol. 38: 17-19

Baranova N.V. (2007) Teoretiko-metodologicheskie aspekty formirovaniya informacionnoj ekonomiki. - M.. $126 \mathrm{p}$. 


\title{
Sciendo
}

\author{
Management Theory and Studies for Rural Business and Infrastructure Development \\ eISSN 2345-0355. 2021. Vol. 43. No. 4: 536-544 \\ Article DOI: https://doi.org/10.15544/mts.2021.48
}

Barefoot, K., Curtis, D., Jolliff, W., Nicholson, J.R., Omohundro, R. (2018). Defining and measuring the digital economy // Bureau of Economic Analysis, United States Department of Commerce. Vol. 25: 15-20

Burma, Z.A. (2016). 4th Industrial Revolution and Innovating in the Digital Economy: World and Turkey Values for 2016 by Global Indicators // International Journal of Research in Engineering, IT and Social Sciences. Vol. 6(12): 20-33.

D’Souza, C., Williams, D. (2017). The Digital Economy. Bank of Canada Review Vol. 14: 32-34

Fayyaz, S. (2019). A Review on Measuring Digital Trade \& E-Commerce as New Economic Statistics Products. Statistika // Statistics \& Economy Journal. Vol. 99 (1): 57-68.

Glushkova, S., Belotserkovich, D., Morgunova, N., Yuzhakova, Y. (2019). The role of smartphones and the internet in developing countries // Revista ESPACIOS. - https://www.revistaespacios.com/a19v40n27/19402710.html [2021 09 09].

Huckle, S., Bhattacharyaa, R., Whitea, M., \& Beloffa, N. (2016). Internet of Things, Blockchain and Shared Economy Applications. Procedia Computer Science. Vol. 98: 461-466.

Titova E. V. (2019) Intellectual potential in the information and communication space of the labor market: new development trends. M.: Infra-m. 124 p.

The World Bank Group (2021). Global Financial Inclusion. https://databank.worldbank.org/reports.aspx?source=global-financial-inclusion [2021 0909 ].

Radu, I., \& Podașcă, R. (2013). The Development of Information and Communication Technologies Sector in the Context of the New Economy // Business Management Dynamics. Vol. 3(4): 1-6.

Sukharev O.S. (2008) Ekonomika tekhnologicheskogo razvitiya. M .: Finance and statistics. 480 p. 